\title{
Histidine and tyrosine decarboxylase activities of lactic acid bacteria in sea bream (Sparus aurata) and sea bass (Dicentrarchus labrax)
}

\author{
Yağmur Nil DOĞAN ${ }^{1, a, ®}$, Şebnem PAMUK ${ }^{2, b}, Z_{\text {Zeki GÜRLER }}^{2, c}$ \\ ${ }^{1}$ Gaziantep University, İslahiye Vocational School, Department of Veterinary, Gaziantep; ${ }^{2}$ Afyon Kocatepe University, Faculty of \\ Veterinary Medicine, Department of Food Hygiene and Technology, Afyonkarahisar, Turkey \\ a ORCID: 0000-0002-1309-0936; ' $\mathrm{b}$ ORCID: 0000-0001-7227-3364; ' ${ }^{\mathrm{O}} \mathrm{CRCID}$ : 0000-0002-9037-2945

Corresponding author: yagmurnildemirel@ $@$ hotmail.com
Received date: 05.08.2019 - Accepted date: 17.03.2020

\begin{abstract}
Biogenic amines (BAs) are formed by decarboxylation of amino acids, amination and transamination of aldehyde and ketone groups. The excess of BAs is harmful to human health. BAs play a significant role in determining the shelf life and quality of foods. Released type and amount of BAs depend on factors such as the quality of the raw material, the diversity of natural microbiota, processing and storage conditions. In fish, the release of BAs is affected primarily from microbial growth as well as other reasons and may cause poisoning. It was aimed to determine the possibility of histidine decarboxylase activity gene ( $h d c)$ and tyrosine decarbocylase activity gene $(t y r d c)$ in lactic acid bacteria (LAB) which were isolated from sea bream and sea bass. A total of $18 \mathrm{Gram}$ positive-catalase negative $\mathrm{LAB}$ was isolated from 84 fish samples from 14 different fish markets. It was found that 12 out of $18 \mathrm{LAB}$ $(67 \%)$ isolates showed negative histidine and tyrosine decarboxylase activities. While 2 out of $6(11 \%)$ LAB isolates were determined positive only tyrosine decarboxylase and 4 of them (22\%) were positive for histidine and tyrosine decarboxylase. As a result of the Polymerase Chain Reaction (PCR), 9 out of $12 \mathrm{LAB}$ isolates (75\%) were found to have histidine decarboxylase activity gene. As a result, the prevalence of histidine decarboxylase activity gene in the LAB has detected more extensive than tyrosine decarboxylase activity gene. Increasing the studies examining the presence of aminobiogenic microorganisms in fish is important for the protection of public health.
\end{abstract}

Keywords: Fish, histidine decarboxylase, lactic acid bacteria, public health, tyrosine decarboxylase.

\section{Çipura (Sparus aurata) ile levrek (Dicentrarchus labrax) balıklarındaki laktik asit bakterilerinin histidin ve tirozin dekarboksilaz aktiviteleri}

Özet: Biyojen aminler (BA), aminoasitlerin dekarboksilasyonu, aldehit ve keton grupların aminasyonu ve transaminasyonu sonucu oluşan fazlası insan sağlığına zararlı olan maddelerdir. Gıdaların raf ömrü ve kalitesinin belirlenmesinde biyojen aminlerin rolü büyüktür. Açığa çıkan BA çeşit ve miktarı hammaddenin kalitesi, doğal mikrobiota çeşitliliği, işleme ve depolama şartları gibi faktörlere bağlı olarak değişiklik göstermektedir. Balıklarda başta mikrobiyel üremeye bağlı olmak üzere birçok faktöre bağlı BA oluşabilmekte ve zehirlenmelere sebep olabilmektedir. Bu çalışmada, çipura ve levrek balıklarından izole edilen laktik asit bakterilerinin $(\mathrm{LAB})$ muhtemel histidin dekarboksilaz $(h d c)$ ve tirozin dekarbokilaz gen $(t y r d c)$ aktivitelerini belirlemek amaçlanmıştır. Toplamda 14 farklı balık marketlerinden toplanan 84 örnekten 18 Gram pozitif katalaz negatif LAB izole edilmiştir. İzole edilen 18 laktik asit bakterisinden 12'si (\%67) histidin ve tirozin dekarboksilaz negatiftir. Geriye kalan 6 LAB izolatının 2'si (\%11) sadece tirozin dekarboksilaz pozitif, 4'ü ise (\%22) histidin ve tirozin dekarboksilaz pozitif belirlenmiştir. Elde edilen toplam 18 LAB izolatının yapılan Polimeraz Zincir Reaksiyonu (PZR) sonucunda 12 laktik asit bakterisinin 9'unun (\%75) histidin dekarboksilaz genine sahip olduğu tespit edilmiştir. Sonuç olarak, LAB izolatlarında histidin dekarboksilaz gen prevalansı tirozin dekarboksilaz geninden fazla bulunmuştur. Aminobiyojenik mikroorganizmaların balıklardaki varlığını inceleyen çalışmaların arttırılması halk sağlığının korunması açısından önem arz etmektedir.

Anahtar sözcükler: Balık, halk sağ $ı \breve{g}$, histidin dekarboksilaz, laktik asit bakterileri, tirozin dekarboksilaz.

\section{Introduction}

Biogenic amines (BAs) can be synthesized by plant and animal metabolism or by the production of microbial carboxylation from free amino acids. They are known as potential indicator substances for determining the shelf life and the quality of foods $(13,31)$. In humans, BAs are used for body activities such as brain activity, the regulation of body temperature and stomach $\mathrm{pH}$, gastric acid secretion, the immune response, cell growth, and differentiation. However, the consumption of foods with high concentrations of BAs can be quite toxic to health (16). Histamine, putrescine, cadaverine, tyramine, $\beta$ - 
phenylethylamine, spermine, and spermidine are the most common BAs in foods $(13,31)$.

Some of BAs, such as histamine and tyramine, are characterized by the control of the nervous system and blood pressure. While histamine causes a decrease in blood pressure, increased capillary permeability, increased gastric acid secretion, and allergic reactions, tyramine causes hypertension $(2,21,35)$. It is reported that histamine is determined for the quality and microbial degradation index in fish and fish products $(32,39,40)$. Histamine related poisoning cause gastrointestinal and neurological disorders (17). The maximum limit is recommended as $100-800 \mathrm{mg} / \mathrm{kg}$ for tyramine. Normally, human monoamine oxidase (MAO) detoxification system can inhibit small amounts of BAs. However, some people have a genetically or pharmacologically impaired MAO detoxification system. For this reason, the low level of BAs concentration may cause adverse effects such as migraine and, hypertension risk $(35,38)$.

Fish-borne intoxications are mostly caused by microbial activities or some substances such as BAs. There are considerably the lowest level biogenic amines in the fresh fish. Many Enterobacteriaceae, Clostridium, Lactobacillus, Lactococcus, Leuconostoc, Enterococcus, Streptococcus, Micrococcus, and Pseudomonas are capable for the formation of BAs in food. Therefore, contamination with these microorganisms can take place at each stage during the transport of fish (33). In addition, these microorganisms can be present in microbiota or introduced through contamination before, during or after the processing of products (18). The aminobiogenic microorganisms can cause decarboxylating of free amino acids and lead to the formation of biogenic amines damaging human health $(3,6,8,9,11,12,13)$. Recently, the genes of diverse pathways producing BA were identified in LAB (18). It was defended that the pathways were dependent to strain specific (5). There are some conditions for BA accumulation in foods such as presence of aminobiogenic microorganisms and favourable conditions for their growth (1). Under these conditions, BA production by $\mathrm{LAB}$ could be controlled at during fermentation (36). Several authors $(3,15)$ have reported the presence of tyrosine and histamine decarboxylase activity in LAB. This study aimed to determine whether lactic acid bacteria isolated from sea bream and sea bass have the tyrosine and histidine decarboxylase genes and a possible risk of histamine and tyramine.

\section{Material and Methods}

A total of 84 fish samples (42 sea bass and 42 sea bream) were collected from fourteen different fish markets between at October-December 2018 and January 2019. The samples were brought to the laboratory under the cold chain and fish bones and skins were removed. All samples were diluted 10 -fold with a sterile $0.85 \% \mathrm{NaCl}$ solution. Then, $0.1 \mathrm{ml}$ of each dilution was spread onto De Man Ragosa Sharpe (MRS) agar (LAB223) and it was incubated at $37^{\circ} \mathrm{C} / 24-48$ hour under anaerobic conditions. After the inoculation, the isolates which were Gram positive and catalase negative isolates were stocked at $18^{\circ} \mathrm{C}$ in MRS broths (LAB094) with glycerine until the next step. Lactobacillus 30a ATCC 33222 and Lactobacillus brevis ATCC 367 were used as positive control strains in each stage of isolation and identification.

Determination of decarboxylase activities: Medium was prepared by the modified Maijala's (23) method (5 $\mathrm{g} / \mathrm{L}$ tryptone; $4 \mathrm{~g} / \mathrm{L}$ yeast extract; $8 \mathrm{~g} / \mathrm{L}$ meat extract; 0.5 $\mathrm{g} / \mathrm{L}$ Tween 80; $0.2 \mathrm{~g} / \mathrm{L} \mathrm{MgSO}_{4} ; 0.05 \mathrm{~g} / \mathrm{L} \mathrm{MnSO}_{4} ; 0.04 \mathrm{~g} / \mathrm{L}$ $\mathrm{FeSO}_{4} ; 0.1 \mathrm{~g} / \mathrm{L} \mathrm{CaCO}_{3} ; 20 \mathrm{~g} / \mathrm{L}$ amino acid; $0.06 \mathrm{~g} / \mathrm{L}$ bromocresol purple; $20 \mathrm{~g} / \mathrm{L}$ agar), and $\mathrm{pH}$ was adjusted to 5.3. The medium separately was added with tyrosine and histidine as precursors. Besides, the medium was prepared without amino acids to control positive reactions. The isolates were incubated at $37^{\circ} \mathrm{C}$ for 24 hours under aerobic conditions. The change of color's medium from yellow to purple showed the presence of amino acid decarboxylase activity (24).

Verification of lactic acid bacteria by polymerase chain reaction: A DNA extraction protocol was performed according to the manufacturer's introduction (Thermo Scientific, K0721). Polymerase Chain Reaction (PCR) amplification of DNA samples was performed (25).The PCR was performed in a $25 \mu \mathrm{l}$ amplification reaction mixture containing $20 \mathrm{mM}$ Tris- $\mathrm{HCl}, \mathrm{pH} 8.0,50$ $\mathrm{mM} \mathrm{KCl} ; 2.5 \mathrm{mM} \mathrm{MgCl} 2$; each $200 \mu \mathrm{M}$ dNTP; $1 \mu \mathrm{M}$ primers, $1 \mathrm{U}$ Taq polymerase and $12.5 \mathrm{ng}$ target DNA (25).

Modified methods were used for amplification (4, 25). The reactions were performed in a Thermal Cycler using the following cycling parameters: $5 \mathrm{~min}$ for first denaturation at $94^{\circ} \mathrm{C}, 35$ cycles of $45 \mathrm{~s}$ at $94^{\circ} \mathrm{C}, 45 \mathrm{~s}$ at $48^{\circ} \mathrm{C}$, $1 \mathrm{~min}$ at $72{ }^{\circ} \mathrm{C}$, and a final extension step of $7 \mathrm{~min}$ at $72^{\circ} \mathrm{C}$. The primer pairs used in the amplification process are shown in Table 1. Amplified products were examined on a $1,8 \%$ agarose gel with stained ethidium bromide.

Table 1. Oligonucleotide primer pairs used in the PCR method for lactic acid bacteria

\begin{tabular}{|c|c|c|c|}
\hline Target Gene ${ }^{\mathrm{a}}$ & Primer Sequence(5'-3') & Amplicon size & Reference \\
\hline \multirow[t]{2}{*}{$h d c$} & F: AGATGGTATTGTTTCTTATG & $367 \mathrm{bp}$ & Marcobal et al. (25) \\
\hline & R: AGACCATACACCATAACCTT & & \\
\hline \multirow[t]{2}{*}{ tyrdc } & F: GCATACCAGAGTCCCTCAAG & $906 \mathrm{bp}$ & Lucas et al. (22) \\
\hline & R: CGGATACGGACGCACAATTG & & \\
\hline
\end{tabular}

${ }^{a} h d c$, histidine decarboxylase; $t y r d c$, tyrosine decarboxylase 


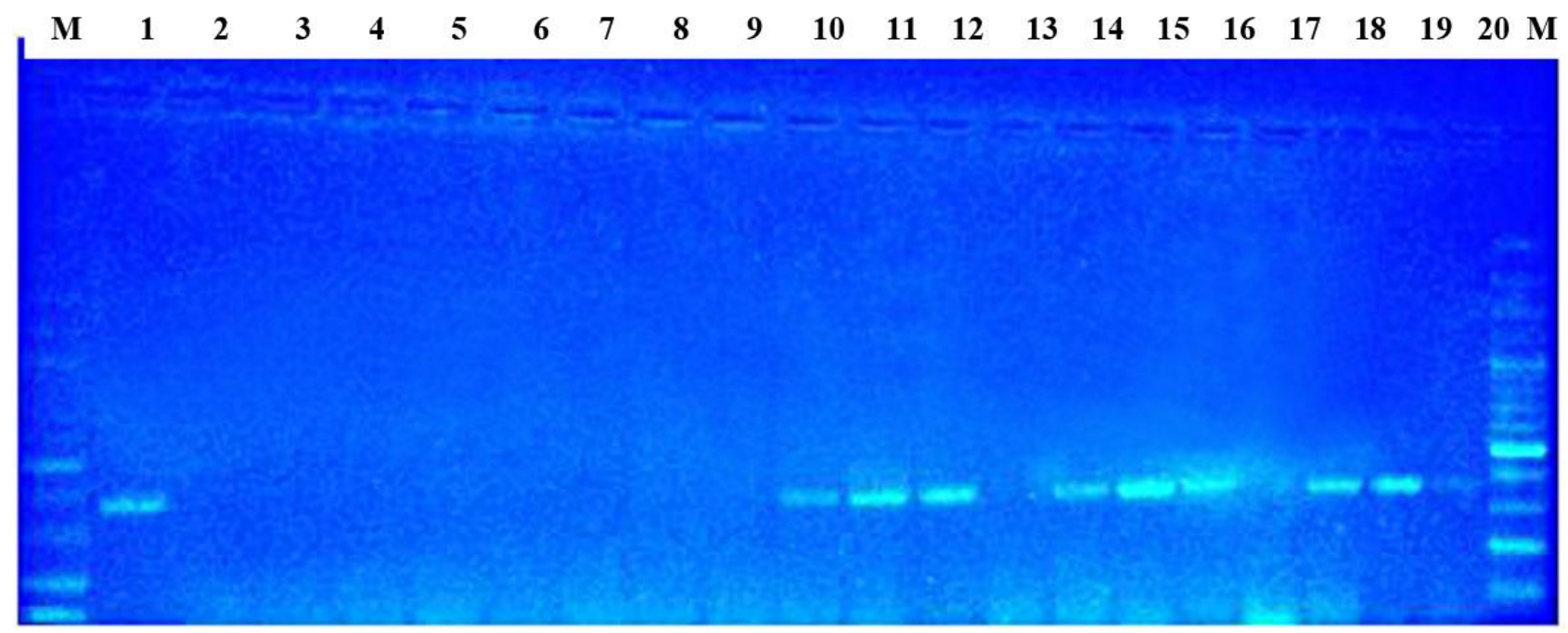

M: 100 bp DNA ladder; 1: Lactobacillus brevis ATCC 367; 2-9: negative LAB isolates from sea bass samples; 10-20: LAB isolates from sea bream samples; $10-12 ; 14-16 ; 18-20$; positive isolates

Figure 1. The tyrosine decarboxylase activity gene PCR gel image of the isolates.

\section{Results}

A total of $18 \mathrm{LAB}$ which was Gram positive-catalase negative was isolated from 84 fish samples from different fish markets. Eleven isolates which were obtained from sea bream were evaluated as negative for a histidine and tyrosine decarboxylase activity and one of sea bass sample was negative, too. Two $(11 \%)$ of the positive isolates showed only a tyramine decarboxylase activity, four $(22 \%)$ isolates had both histamine and tyramine decarboxylase activities.

According to the PCR study, 18 isolates did not have a tyrdc gene (data not shown). Hdc gene was determined in 9 of $12 \mathrm{LAB}$ which were shown negative reaction in cultural method for both amino acid. The tyrosine decarboxylase activity gene PCR gel image of the isolates is shown in Figure 1.

\section{Discussion and Conclusion}

Histamine formation is the critical control point during the production of fish products (37). It has been found that 7 of $27 \mathrm{LAB}$ isolates showed a decarboxylase activity, especially tyrosine (34). On the contrary, it has not been found any $h d c$ gene in 74 LAB isolates. It was identified a tyrdc gene in 34 isolates which belonged to Enterococcus spp (29). The amino acid decarboxylase capacity depends on the species of microorganisms and environmental factors $(8,9,26,28,34)$. It is reported that the detection of histamine producing microorganisms is not reliable with classical culture techniques (37). It was widely used in Niven et al.'s (30) modified medium for classical cultural methods $(20,27,41)$. However, several researchers $(14,19)$ reported that cultural methods using Niven et al. (30) medium had a false positive or negative result. It has been concluded that $13(17 \%)$ of lactic acid bacteria isolated from 77 fermented fish products were able to the decarboxylation of amino acids (7). Our findings have a negative relation with Dapkevicius et al. (7)'s study because of the differences between preparation of material and fish product. If LAB does not have a tyrdc gene activity, it does not mean that it cannot present tyramine in fish (29). Even though histamine forming microorganisms lose viability in the frozen-thawed fish, histamine can be detected in fish (10). BAs cannot be removed by technological methods such as freezing or heat treatment. Therefore, the absence of aminobiogenic microorganisms in fish does not indicate that the product can be reliable.

According to our results, it is determined that classical culture methods could give false positive or false negative results for the determination of BAs decarboxylase. It is recommended that molecular methods should be used to eliminate this complexity and to take faster results. In sea breams, LAB with histidine decarboxylase is more than sea basses. For this reason, the public should be made aware of the possibility of BA in fish especially during transport to non-coastal areas. It is mainly focused on Gram negative microorganisms related to the formation of biogenic amines in fish. However, it should be kept in mind that LAB may cause unwanted conditions such as the formation of BAs as well as desired properties such as fermentation or bacteriocin production in foods. Therefore, it is important for public health to know the aminobiogenic LAB isolated from fish. To prevent BA formation and to ensure food safety, it is required that hygienic quality during hunting, processing, distribution, storage conditions, and marketing should be 
taken into consideration. Especially, during transport to non-coastal areas, there is a need that fish and fish products must be brought under controlled conditions.

\section{Financial Support}

This research received no grant from any funding agency/sector.

\section{Ethical Statement}

This study does not present any ethical concerns.

\section{Conflict of Interest}

The authors have no conflicts of interest relevant to this article.

\section{References}

1. Arena ME, Landete JM, Manca de Nadra MC, et al (2008): Factors affecting the production of putrescine from agmatine by Lactobacillus hilgardii X1B isolated from wine. J Appl Microbiol, 105, 158-165.

2. Aygün O (2003): Biyojen aminler- süt ve süt ürünlerindeki varliğl ve önemi. J Res Vet Med, 22, 91-95.

3. Burdychova R, Komprda T (2007): Biogenic amineforming microbial communities in cheese. FEMS Microbiol Lett, 276, 149-155.

4. Coton E, Coton M (2005): Multiplex PCR for colony direct detection of Gram-positive histamine-and tyramineproducing bacteria. J Microbiol Met, 63, 296-304.

5. Coton E, Coton M (2009): Evidence of horizontal transfer as origin of strain to strain variation of the tyramine production trait in Lactobacillus brevis. Food Microbiol, 26, 52-57.

6. Çoban EÖ, Patır B (2008): Investigation of histamine level and some chemical quality parameters in fish consumed in Elazı̆̆ city. Int J Sci Tech, 3, 59-65.

7. Dapkevicius MLE, Nout MR, Rombouts FM, et al (2000): Biogenic amine formation and degradation by potential fish silage starter microorganisms. Int $\mathrm{J}$ Food Microbiol, 57, 107-114.

8. Deepika Priyadarshani WM, Rakshit SK (2011): Screening selected strains of probiotic lactic acid bacteria for their ability to produce biogenic amines (histamine and tyramine). Int J Food Sci Technol, 46, 2062-2069.

9. Fernández M, Linares DM, Rodríguez A, et al (2007): Factors affecting tyramine production in Enterococcus durans IPLA655. Appl Microbiol Biotechnol, 73, 14001406.

10. Fuji T, Kurihara K, Okuzumi M (1994): Viability and histidine decarboxylase activity of halophilic histamineforming bacteria during frozen storage. J Food Prot, 57, 611-613.

11. Joosten HMLJ (1988): Conditions allowing the formation of biogenic amines in cheese. 3. factors influencing the amongs formed. Neth. Milk Dairy J, 41, 329-357.

12. Joosten HMLJ, Stadhouders J (1987): Conditions allowing the formation of biogenic amines in cheese. 1 . decarboxylative properties of starter bacteria. Neth Milk Dairy J, 41, 247-258.
13. Kantaria UD, Gokani RH (2011): Quality and safety of biogenic amines. Int J Res Pharm Biomed Sci, 2, 14611468.

14. Kim SH, Ben-Gigirey B, Barros-Velazquez $J$, et al (2000): Histamine and biogenic amine production by Morganella morganii isolated from temperature-abused albacore. J Food Prot, 63, 244-251.

15. Komprda T, Burdychová R, Dohnal V, et al (2008): Tyramine production in Dutch-type semi-hard cheese from two different producers. Food Microbiol, 25, 219-227.

16. Ladero V, Calles-Enríquez M, Fernández $M$, et al (2010): Toxicological effects of dietary biogenic amines. Curr Nutr Food Sci, 6, 145-156.

17. Lehane L, Olley J (2000): Histamine fish poisoning revisited. Int J Food Microbiol, 58, 1-37.

18. Linares DM, Martín M, Ladero V, et al (2011): Biogenic amines in dairy products. Crit Rev Food Sci, 51, 691-703.

19. López-Sabater EI, Rodríguez-Jerez J, HernándezHerrero M, et al (1996): Incidence of histamine-forming bacteria and histamine content in scombroid fish species from retail markets in the Barcelona area. Int $\mathrm{J}$ Food Microbiol, 28, 411-418.

20. Lopez-Sabater EI, Rodriguez-Jerez JJ, Roig-Sagues AX, et al (1994): Bacteriological quality of tuna fish (Thunnus thynnus) destined for canning: effect of tuna handling on presence of histidine decarboxylase bacteria and histamine level. J Food Prot, 57, 318-323.

21. Loser C (2000): Polyamines in human and animal milk. Br J Nutr, 84, 55-58.

22. Lucas P, Landete J, Coton M, et al (2003): The tyrosine decarboxylase operon of Lactobacillus brevis IOEB 9809: characterization and conservation in tyramine-producing bacteria. FEMS Microbiol Lett, 229, 65-71.

23. Maijala RL (1993): Formation of histamine and tyramine by some lactic acid bacteria in MRS broth and modified decarboxylation agar. Lett Appl Microbiol, 17, 40-43.

24. Mangia NP, Trani A, Di Luccia A, et al (2013): Effect of the use of autochthonous Lactobacillus curvatus, Lactobacillus plantarum and Staphylococcus xylosus strains on microbiological and biochemical properties of the Sardinian fermented sausage. Eur Food Res Technol, 236, 557-566.

25. Marcobal A, de las Rivas B, Moreno-Arribas MV, et al (2005): Multiplex PCR method for the simultaneous detection of histamine-, tyramine-, and putrescineproducing lactic acid bacteria in foods. J Food Prot, 68 , 874-878.

26. Marcobal A, Martín-Álvarez PJ, Moreno-Arribas MV, et al (2006): A multifactorial design for studying factors influencing growth and tyramine production of the lactic acid bacteria Lactobacillus brevis CECT4669 and Enterococcus faecium BIFI-58. Res Microbiol, 157, 417424.

27. Marino M, Maifreni M, Moret S, et al (2000): The capacity of Enterobacteriaceae species to produce biogenic amines in cheese. Lett Appl Microbiol, 31, 169-173.

28. Mazzoli R, Lamberti C, Coissson JD, et al (2009): Influence of ethanol, malate and arginine on histamine production of Lactobacillus hilgardii isolated from an Italian red wine. Amino Acids, 36, 81-89. 
29. Muñoz-Atienza E, Landeta G, de las Rivas B, et al (2011): Phenotypic and genetic evaluations of biogenic amine production by lactic acid bacteria isolated from fish and fish products. Int J Food Microbiol, 146, 212-216.

30. Niven CF, Jeffrey MB, Corlett DA (1981): Differential plating medium for quantitative detection of histamineproducing bacteria. Appl Environ Microbiol, 41, 321-322.

31. Özbay Doğu S, Sarıçoban C (2015): Balık ve balık ürünlerinde biyojen aminler ve önemi. KSÜ Doğa Bil Derg, 18, 19-28.

32. Özoğul F, Küley E, Özoğul, Y (2004): Balık ve balık ürünlerinde oluşan biyojen aminler. Su Ürünleri Dergisi, 21, 375-381.

33. Pascual-Anderson MR, Calderen-Pascual V (2000): Microbiologa Alimentaria. Metodologia Para Alimentos Y Bebidas. Diaz de Santos, S.A., Madrid, Spain.

34. Pons-Sánchez-Cascado S, Vidal-Carou MC, MarinéFont A, et al (2005). Influence of the freshness grade of raw fish on the formation of volatile and biogenic amines during the manufacture and storage of vinegar-marinated anchovies. J Agric Food Chem, 53, 8586-8592.
35. Silla Santos MH (1996): Biogenic amines: their importance in foods. Int J Food Microbiol, 29, 213-231.

36. Spano G, Russo P, Lonvaud-Funel A, et al (2010): Biogenic amines in fermented foods. Eur J Clin Nutr, 64, 95-100.

37. Takahashi H, Kimura B, Yoshikawa M, et al (2003): Cloning and sequencing of the histidine decarboxylase genes of gram-negative, histamine-producing bacteria and their application in detection and identification of these organisms in fish. Appl Environ Microbiol, 69, 2568-2579.

38. Ten Brink B, Damink C, Joosten HMJL, et al (1990): Occurrence and formation of biologically active amines in foods. Int J Food Microbiol, 11, 73-84.

39. Veciana Nogués MT, Vidal Carou MC, Marine Font A (1989): Histamine and tyramine in preserved and semi preserved fish products. J Food Sci, 54, 1653-1655.

40. Vidal-Carou MC, Izquierdo-Pulido ML, Martin-Morro MC (1990): Histamine and tyramine in meat products: relationship with meat spoilage. Food Chem, 37, 239-249.

41. Yoshinaga DH, Frank HA (1982): Histamine-producing bacteria in decomposing skipjack tuna (Katsuwonus pelamis). Appl Environ Microbiol, 44, 447-452. 